\title{
Plant growth-promoting traits of Pseudomonas geniculata isolated from chickpea nodules
}

\author{
Subramaniam Gopalakrishnan • Vadlamudi Srinivas • \\ Bandikinda Prakash • Arumugam Sathya • \\ Rajendran Vijayabharathi
}

Received: 14 July 2014/ Accepted: 17 October 2014/Published online: 1 November 2014

(C) The Author(s) 2014. This article is published with open access at Springerlink.com

\begin{abstract}
A bacterium, isolated from nodules of chickpea grown in alluvial soils of Haryana state of India, designated as IC-76 was characterized for in vitro plant growth-promoting (PGP) properties and further evaluated under greenhouse, on-station and on-farm field conditions for PGP activity in chickpea. The isolate IC-76 produced indole acetic acid, siderophore, hydrocyanic acid, cellulase, protease, and $\beta$-1,3-glucanase. When the bacterium was evaluated individually for their PGP potential in the greenhouse on chickpea and in combination with five Streptomyces sp. (strains CAI-24, CAI-121, CAI-127, KAI32, and KAI-90; demonstrated earlier as biocontrol potential against Fusarium wilt disease in chickpea), the traits, including nodule number and weight, shoot, and root weight, pod number and weight, seed number and weight, available phosphorus and \% organic carbon were found significantly, enhanced over un-inoculated control. In the on-station and on-farm field conditions, IC-76 significantly enhanced nodule number and weight, shoot, and root weight, stover and grain yield and total dry matter. In the rhizosphere (0-15 cm soil), the bacterium also significantly enhanced the total nitrogen, available phosphorus and \% organic carbon. The sequence of 16S rDNA gene of the IC76 was matched with Pseudomonas geniculata in BLAST analysis. This study demonstrates that IC-76 has the potential for PGP in chickpea.
\end{abstract}

Keywords Plant growth promotion - Pseudomonas geniculata $\cdot$ Chickpea $\cdot$ Field evaluation

S. Gopalakrishnan $(\varangle) \cdot$ V. Srinivas · B. Prakash · A. Sathya · R. Vijayabharathi

International Crops Research Institute for the Semi-Arid Tropics (ICRISAT), Patancheru 502 324, Telangana, India

e-mail: s.gopalakrishnan@cgiar.org

\section{Introduction}

Plant growth-promoting (PGP) microbes are soil bacteria that colonize rhizoplane and rhizosphere and enhance plant growth when inoculated artificially onto the soil or seeds. PGP bacteria can directly or indirectly affect plant growth through various mechanisms which includes fixation of atmospheric nitrogen (Soares et al. 2006), solubilization of minerals (Basak and Biswas 2009; Panhwar et al. 2012), synthesis of various enzymes and phyto-hormones (Patten and Glick 2002; Cheng et al. 2007), and inhibition of phytopathogens (Hao et al. 2011; Gopalakrishnan et al. 2011a, $b, c)$. Different functional and taxonomic groups of microbes are reported to have PGP traits which includes free living bacteria, such as Bacillus, Pseudomonas, Erwinia, Caulobacter, Serratia, Arthrobacter, Micrococcus, Flavobacterium, Chromobacterium, Agrobacterium, Hyphomicrobium, and symbiotic $\mathrm{N}_{2}$ fixing bacteria, such as Rhizobium, Bradyrhizobium, Sinorhizobium, Azorhizobium, Mesorhizobium, and Allorhizobium (Vessey 2003). The use of PGP microbes has increased in many parts of the world due to their significant contribution in growth and yield which has been demonstrated in crops, such as tomato, wheat, rice, bean, and pea (Tokala et al. 2002; Nassar et al. 2003; ElTarabily 2008; Figueiredo et al. 2008; Sadeghi et al. 2012; Gopalakrishnan et al. 2012a, b, 2013a, b). In legumes, symbiotic bacteria including Rhizobium, Mesorhizobium, and Bradyrhizobium are reported to benefit plant growth and yield (Pandey and Maheshwari 2007; Joshi et al. 2008; Kumar et al. 2011). Besides, several non-symbiotic bacteria, including Pseudomonas, Bacillus, Klebsiella, Azotobacter, Azospirillum, and Azomonas were also reported to increase the plant growth by the same mechanisms followed by Rhizobium sp. (Glick 1995; Ahemad and Kibret 2014). Number of other bacteria such as Pantoeaagglomerans, 
Klebsiellapneumoniae, Beijerinckia sp., and Azoarcus sp. were also reported to fix atmospheric nitrogen and promote plant growth (Riggs et al. 2001). Minorsky (2008) demonstrated vigorous colonization of a PGP strain Pseudomonas fluorescens B 16 in the roots of tomato resulting in higher yield. In chickpea, fluorescent pseudomonads were reported to promote plant growth, nodulation, and nitrogen fixation (Parmer and Dadarwal 1999). Though a number of literatures are available for PGP of various functional groups of bacteria, the demonstration of PGP bacteria under on-station and on-farm field conditions are scarce. Therefore, the present investigation was aimed to characterize and evaluate a root nodule bacterium isolated from chickpea nodule for its ability to promote plant growth in chickpea under greenhouse, on-station and on-farm field conditions.

\section{Materials and methods}

A bacterium designated as IC-76, acquired from microbial gene bank at ICRISAT, was used extensively in this study. IC-76 was originally isolated from the nodules of chickpea (Cicer arietinum L.) by ICRISAT from the alluvial soils of Haryana, India. The actinomycetes CAI-24 (Streptomyces tsusimaensis; NCBI Accession Number: JN400112), CAI121 (Streptomyces caviscabies; NCBI Accession Number: JN400113), CAI-127 (Streptomyces setonii; NCBI Accession Number: JN400114), KAI-32 (Streptomyces africanus; NCBI Accession Number: JN400115) and KAI-90 (Streptomyces sp; NCBI Accession Number: JN400116), reported earlier by us as potential for biocontrol traits against Fusarium wilt in chickpea (Gopalakrishnan et al. 2011c), were used in this investigation.

The bacterium was evaluated for production of indole acetic acid (IAA), $\beta$-1,3-glucanase, hydrocyanic acid $(\mathrm{HCN})$, siderophore, cellulase, lipase, chitinase, protease, and P-solubilizing capacity. IC-76 was estimated for IAA production in yeast extract mannitol (YEM) broth supplemented with L-tryptophan $\left(1 \mu \mathrm{g} \mathrm{mL}^{-1}\right)$ as per the protocols of Patten and Glick (1996). $\beta$-1,3-glucanase was done as per the protocols of Singh et al. (1999) and Gopalakrishnan et al. (2014) in tryptic soy broth, supplemented with $1 \%$ colloidal chitin (w/v). One unit of $\beta$-1,3-glucanase activity was defined as the amount of enzyme that liberated $1 \mu \mathrm{mol}$ of glucose hour ${ }^{-1}$ at defined conditions.

HCN was qualitatively estimated by sulfocyanate method (Lorck 1948). In brief, IC-76 was grown in triplicates in YEM agar amended with glycine $\left(4.4 \mathrm{~g} \mathrm{~L}^{-1}\right)$. Sterilized Whatman filter paper no. 1 (one sheet of $8 \mathrm{~cm}$ diameter) was soaked in $1 \%$ picric acid (in $10 \%$ sodium carbonate) for a minute and stuck underneath the Petri plate lids. The Petri plates were sealed with parafilm and incubated at $28{ }^{\circ} \mathrm{C}$ for three days. Development of reddish brown color on the Whatman filter paper indicated $\mathrm{HCN}$ production. The experiment was conducted three times. Observations were noted on a $0-3$ rating scale, based on the intensity of the reddish brown color, as follows: 0 , no color; 1, light reddish brown; 2, medium reddish brown, and 3 , dark reddish brown.

Siderophore production was assessed in King's B agar as per the protocol of Schwyn and Neilands (1987). The standardized protocols of Hendricks et al. (1995) were used in cellulose congo red agar to evaluate the cellulase production. The lipase and protease production was estimated as per the protocols of Bhattacharya et al. (2009) in tween 80 agar and casein agar, respectively. Chitinase production was determined in minimal media with $5 \%$ colloidal chitin as per the protocols of Hirano and Nagao (1988). All the experiments were conducted three times in triplicated treatments. Observations of the IC-76 to siderophore, cellulase, lipase, and protease were noted on a $0-4$ rating scale as follows: 0 , no halo zone; 1 , halo zone of $<1 \mathrm{~mm}$; 2 , halo zone of $1-3 \mathrm{~mm} ; 3$, halo zone of $4-6 \mathrm{~mm}$; halo zone of 7-9 $\mathrm{mm}$, and above. Chitinase production was noted on a $0-5$ rating scale as follows: 0 , no halo zone; 1 , halo zone of 1-5 mm; 2, halo zone of 6-10 $\mathrm{mm}$; 3 , halo zone of 11-15 mm; 4, halo zone of 16-20 mm, and 5, halo zone of $21 \mathrm{~mm}$, and above.

IC-76 was screened for its phosphate solubilizing ability on Pikovskaya agar (Pikovskaya 1948). The bacterium was streaked on Pikovskaya agar and incubated at $28^{\circ} \mathrm{C}$ for three days. The presence of halo zone around the bacterium indicated positive.

IC-76 was evaluated for their PGP potential in greenhouse on chickpea as mono-culture and as co-inoculation with five strains of Streptomyces sp., such as CAI-24, CAI121, CAI-127, KAI-32, and KAI-90. A total of eight treatments (IC-76, IC-76 + CAI-24, IC-76 + CAI-121, IC-76 + CAI-127, IC-76 + KAI-32, IC-76 + KAI-90, $\mathrm{IC}-76+$ the consortia of five Streptomyces sp. and uninoculated control) were made with six replications. Pot mixture (1000 g) was prepared by mixing black soil, sand, and farmyard manure at 3:2:2 and placed in $20 \mathrm{~cm}$ diameter plastic pots. Chickpea seeds (Kabuli variety ICCV-2 which matures at 85-90 days) were surface sterilized with sodium hypochlorite $(2.5 \%$ for $5 \mathrm{~min}$ ) and rinsed thoroughly with sterilized water. The sterilized seeds were transferred into IC-76 culture broth $\left(10^{8} \mathrm{CFU} \mathrm{mL}^{-1}\right.$; grown in YEM broth separately) and incubated for $50 \mathrm{~min}$. At the end of incubation, where required, the seeds were further transferred into the respective Streptomyces strains $\left(10^{8}\right.$ CFU mL ${ }^{-1}$; grown in starch casein broth separately) for $50 \mathrm{~min}$ before being sown in the pots (three seeds/pot but thinned to one after one week). Booster doses of IC-76/ Streptomyces strains $\left(5 \mathrm{~mL}\right.$ per pot, $10^{8} \mathrm{CFU} \mathrm{mL}^{-1}$ ) were applied at 15, 30, 45, and 60 days after sowing by soil 
drench method. Plants were irrigated once every three days with $30 \mathrm{~mL}$ sterilized distilled water. PGP parameters, including plant height, leaf area and weight, nodule number and weight, stem weight and root weight, length and volume, were determined at day 30 after sowing. At harvest, pod weight and number and seed weight and number were recorded. Soil samples were collected $(0-15 \mathrm{~cm}$ soil profile) at harvesting and analyzed for soil chemical traits including total $\mathrm{N}$, available $\mathrm{P}$, and \% organic carbon as per the protocols of Novozamsky et al. (1983), Olsen and Sommers (1982) and Nelson and Sommers (1982), respectively.

IC-76 was evaluated for PGP potential under on-station field conditions. The experiment was conducted in 2013-14 cropping seasons (post-rainy) at ICRISAT, Patancheru, Andhra Pradesh, India with chickpea variety ICCV-2, which normally yields $1.1-1.2 \mathrm{t} \mathrm{ha}^{-1}$. Soils at the experimental site are classified as Vertisol (fine montmorillonitic isohyperthermic typic pallustert) having $26 \%$ sand, $21 \%$ silt, and $52 \%$ clay with alkaline $\mathrm{pH}$ of 7.7-8.6 and organic carbon content of $0.4-0.6 \%$. The mineral content of the top $15 \mathrm{~cm}$ rhizosphere soil include $24.7 \mathrm{mg} \mathrm{kg}^{-1}$ soil of available nitrogen, $8.6 \mathrm{mg} \mathrm{kg}^{-1}$ soil of available phosphorus and $298 \mathrm{mg} \mathrm{kg}^{-1}$ soil of available potassium. The experiment was laid out in a randomized complete block design (RCBD) with three replicates and subplot sizes of $4 \mathrm{~m} \times 3$ ridges. IC-76 was grown on YEM broth at $28{ }^{\circ} \mathrm{C}$ for three days and further evaluated for their PGP traits. The control plots contained no IC-76 strain. Chickpea seed was treated with IC-76 (containing $10^{8}$ CFU mL ${ }^{-1}$ ) for $50 \mathrm{~min}$ and sown on 1 st November 2013 at a row-to-row spacing of $60 \mathrm{~cm}$ and a plant-to-plant spacing of $10 \mathrm{~cm}$. IC-76 $\left(1,000 \mathrm{~mL} ; 10^{8} \mathrm{CFU} \mathrm{mL}^{-1}\right)$ was applied once in 15 days on the soil close to the plant until the flowering stage. Irrigation was done on 21 days and 49 days after sowing. Weeding was done as and when required. No serious insect pests or phytopathogen attack were observed during the cropping period. The crop was harvested manually on 6th Feb 2014. At 30 days after sowing, plant height, nodule number, and weight and shoot and root weight whereas at harvest stover yield $\left(\mathrm{t} \mathrm{ha}^{-1}\right)$, grain yield (th $\left.\mathrm{a}^{-1}\right)$, total dry matter $\left(\right.$ th $\left.^{-1}\right)$, pod weight $(\mathrm{g}$ plant ${ }^{-1}$ ), seed number (plant ${ }^{-1}$ ), and 1000 seed weight (g) were noted. Soil samples were collected from 0-15 cm soil profile at flowering and harvest stages and analyzed for soil chemistry [total nitrogen ( $\mathrm{ppm}$ ), available phosphorus (ppm) and \% organic carbon as per the protocols of Novozamsky et al. (1983); Olsen and Sommers (1982) and Nelson and Sommers (1982), respectively].

IC-76 was also evaluated under on-farm field conditions at Mennipadu and Ramapuram villages (220 and $214 \mathrm{~km}$, respectively, from ICRISAT) of Mahbubnagar districts of Andhra Pradesh, India. The experiment was conducted at four farmer's field (one acre each) in each village in 2013-14 post-rainy seasons with Kabuli chickpea variety ICCV-2 onVertisol under rain fed conditions. The crop was sowed on 15th October 2013 and harvested manually on 21st January 2014. All the agronomic practices were followed as per on-station field conditions. Plant growth parameters including stover + pod yield $\left(\mathrm{t} \mathrm{ha}^{-1}\right)$, grain yield $\left(\mathrm{t} \mathrm{ha}^{-1}\right)$, shoot and pod weight $\left(\mathrm{g} \mathrm{plant}^{-1}\right)$, number of pods $\left(\right.$ plant $\left.^{-1}\right)$, and number of seeds $\left(\right.$ plant $^{-1}$ ) were determined at harvest.

For molecular identification of IC-76, pure culture of IC-76 was grown in YEM broth until log phase (three days). Genomic DNA was isolated as per the protocols of Bazzicalupo and Fani (1995) whereas 16S rDNA gene was amplified using universal primer 1492R (5' -TAC GGY TAC CTT GTT ACG ACT T-3') and 27F (5' - AGA GTT TGA TCM TGG CTC AG-3') as per the conditions described by Pandey et al. (2005). The PCR product was sequenced at Macrogen Inc. Seoul, Korea. The sequences obtained from Macrogen Inc. were compared with those from the GenBank using the BLAST program (Alschul et al. 1990), aligned using the Clustal W software (Thompson et al. 1997) and phylogenetic trees inferred using the MEGA version 4 program (Tamura et al. 2007) by neighbor-joining method (Saitou and Nei 1987). The nucleotide sequences of IC-76 were submitted to GenBank and the NCBI GenBank accession number was obtained.

For statistical analysis, the data were subjected to Analysis of Variance (ANOVA; GenStat 10.1 version 2007, Lawes Agricultural Trust, Rothamsted Experimental Station) to evaluate the efficiency of PGP agent's application in the greenhouse and field studies. Significance of differences between the treatment means was tested at $P<0.001,0.01$, and 0.05 .

\section{Results and discussion}

Plant growth-promoting microbes having the ability to fix biological nitrogen would have an advantage in counterbalancing the loss of nitrogen from soils. In the present investigation, a bacterium (IC-76) isolated from the nodules of chickpea was characterized for in vitro PGP properties and further evaluated in the greenhouse and onstation and on-farm field conditions for PGP activity in chickpea. PGP microbes enhance host plant growth by exploiting different mechanisms. In the present study, IC76 produced IAA, siderophore, $\mathrm{HCN}$, cellulase, protease, and $\beta$-1,3-glucanase while it did not produce lipase and chitinase and solubilize phosphorus (Table 1). Among the PGP attributes studied, IC-76 produced large volumes of IAA (327 $\left.\mathrm{g} \mathrm{mL}^{-1}\right)$ and siderophore (45\% units). IAA producing bacteria are known to stimulate seed 
germination, initiate lateral and adventitious root formation and increase root surface area and length thereby provides the host plant greater access to water and soil nutrients (Ahemad and Kibret 2014). Siderophores act as solubilizing agents for iron from minerals under conditions of iron limitation (Indiragandhi et al. 2008). In addition, siderophores form stable complexes with heavy metals, including $\mathrm{U}, \mathrm{Np}, \mathrm{Al}, \mathrm{Cu}, \mathrm{Cd}, \mathrm{In}, \mathrm{Ga}, \mathrm{Zn}$, and $\mathrm{Pb}$ and increases the soluble metal concentration (Rajkumar et al. 2010), thus, it help to alleviate the stresses imposed on plants by heavy metals in soils. HCN production by bacteria is reported to play a role in disease suppression, as in the case of tobacco where Pseudomonas fluorescens helped suppression of black root rot disease (Haas et al. 1991). Cellulase and protease-producing microorganisms play an important role

Table 1 In vitro PGP traits of IC-76

\begin{tabular}{|c|c|c|}
\hline Trait & Concentration/rating & SE \\
\hline Indole acetic acid (IAA; $\left.\mu \mathrm{gml}^{-1}\right)$ & 327.0 & 7.350 \\
\hline Siderophore (\% units) & 44.7 & 0.220 \\
\hline Hydrocyanic acid (HCN) & 2.0 & 0.000 \\
\hline Cellulase & 2.0 & 0.030 \\
\hline Lipase & 0.0 & 0.000 \\
\hline Chitinase & 0.0 & 0.000 \\
\hline Protease & 2.0 & 0.000 \\
\hline$\beta-1,3-$-Glucanase (\% units) & 0.9 & 0.003 \\
\hline P-solubilization & 0.0 & 0.000 \\
\hline
\end{tabular}

$S E$ standard error in the organic matter decomposition, nutrient mineralization, and PGP (Lima et al. 1998). The cell wall of plant pathogenic fungi, for instance Fusarium oxysporum, is composed of layers of $\beta-1,3$-glucan and lysis of this by $\beta$ 1,3-glucanase-producing bacteria leads to leakage of cell contents and collapse of the pathogenic fungi (Singh et al. 1999). It is concluded that the bacterial strain isolated from the chickpea rhizosphere contains multi-trait of PGP, and therefore, IC-76 can be exploited not only for PGP but also for biological control of plant pathogens and/or degradation of organic residues.

When IC-76 evaluated for its PGP potential under green house, at 30 days after sowing, IC-76 significantly enhanced PGP traits on leaf area (up to $9 \%$ ), root weight (up to $9 \%$ ), length (up to $20 \%$ ), and volume (up to $10 \%$ ) and stem weight (up to $7 \%$ ) over un-inoculated control. Besides this, IC-76 either in combination with individual Streptomyces sp. or with consortia of Streptomyces sp. significantly enhanced all the PGP traits including plant height (up to $11 \%$ ), leaf area (up to $35 \%$ ), leaf weight (up to $133 \%$ ), nodule number (up to $103 \%$ ) and weight(up to $181 \%$ ), root weight (up to $35 \%$ ), length (up to $109 \%$ ), and volume (up to $49 \%$; Table 2). Similar trend was observed at harvest as well where IC-76 in combination with individual Streptomyces sp. or consortia of Streptomyces sp. significantly enhanced the PGP traits of chickpea than the application of IC-76 alone (Table 3). At harvest, IC-76 as individual and with consortia of Streptomyces sp. significantly enhanced total $\mathrm{N}$ (up to $22 \%$ ), available $\mathrm{P}$ (up to $59 \%$ ), and $\%$ organic carbon (up to $8 \%$ ) over un-

Table 2 Effect of IC-76, as individual culture and co-inoculation with PGP actinomycetes, on growth performance of chickpea at 30 days after sowing under greenhouse conditions

\begin{tabular}{|c|c|c|c|c|c|c|c|c|c|}
\hline Treatments & $\begin{array}{l}\text { Plant height } \\
(\mathrm{cm})\end{array}$ & $\begin{array}{l}\text { Leaf } \\
\text { area }\left(\mathrm{cm}^{2}\right)\end{array}$ & $\begin{array}{l}\text { Leaf } \\
\text { weight }(\mathrm{g})\end{array}$ & $\begin{array}{l}\text { Nodule } \\
\text { number }\end{array}$ & $\begin{array}{l}\text { Nodule } \\
\text { weight } \\
(\mathrm{mg})\end{array}$ & $\begin{array}{l}\text { Root } \\
\text { weight (mg) }\end{array}$ & $\begin{array}{l}\text { Stem } \\
\text { weight }(\mathrm{mg})\end{array}$ & $\begin{array}{l}\text { Root } \\
\text { length }(\mathrm{cm})\end{array}$ & $\begin{array}{l}\text { Root } \\
\text { volume } \\
\left(\mathrm{cm}^{3}\right)\end{array}$ \\
\hline Control & 24.7 & 65 & 0.30 & 7.7 & 3.1 & 87 & 108 & 552 & 1.96 \\
\hline IC-76 & 24.8 & 71 & 0.30 & 7.8 & 3.1 & 95 & 115 & 660 & 2.15 \\
\hline CAI-24 + IC-76 & 27.3 & 79 & 0.36 & 11.0 & 6.5 & 117 & 142 & 723 & 2.76 \\
\hline CAI-121 + IC-76 & 26.3 & 71 & 0.31 & 8.2 & 4.2 & 103 & 192 & 951 & 2.44 \\
\hline CAI-127 + IC-76 & 26.8 & 81 & 0.51 & 7.8 & 3.0 & 107 & 243 & 840 & 2.43 \\
\hline KAI-32 + IC-76 & 27.3 & 82 & 0.51 & 11.0 & 5.2 & 105 & 295 & 894 & 2.52 \\
\hline KAI-90 + IC-76 & 27.2 & 82 & 0.49 & 8.3 & 3.2 & 112 & 263 & 704 & 2.36 \\
\hline Consortia + IC-76 & 24.8 & 88 & 0.70 & 15.6 & 8.7 & 105 & 368 & 1156 & 2.91 \\
\hline Mean & 26.2 & 77 & 0.44 & 9.7 & 4.6 & 104 & 206 & 810 & 2.44 \\
\hline $\mathrm{SE} \pm$ & $0.60 * *$ & $3.1 * *$ & $0.028 *$ & $0.45 * * *$ & $0.41 * * *$ & $4.1 * *$ & $12.7 * * *$ & $29.3 * * *$ & $0.118 * * *$ \\
\hline LSD (5 \%) & 1.83 & 9.5 & 0.085 & 1.36 & 1.24 & 12.3 & 38.7 & 89.0 & 0.358 \\
\hline $\mathrm{CV} \%$ & 4 & 7 & 11 & 8 & 15 & 7 & 9 & 6 & 9 \\
\hline
\end{tabular}

$S E$ standard error, $L S D$ least significant difference, $C V$ coefficient of variance

** Statistically significant at 0.01

*** Statistically significant at 0.001 
Table 3 Effect of $P$. geniculata IC-76, as individual culture and co-inoculation with PGP actinomycetes, on yield performance of chickpea and soil nutrient traits at harvest stage under greenhouse conditions

\begin{tabular}{llllllll}
\hline Treatments & Pod weight $(\mathrm{g})$ & Pod number & Seed weight $(\mathrm{g})$ & Seed number & Total N (ppm) & Available P (ppm) & \% Organic carbon \\
\hline Control & 5.94 & 23 & 3.5 & 23 & 2153 & 67.4 & 2.14 \\
IC-76 & 7.09 & 26 & 5.4 & 29 & 2562 & 71.6 & 2.25 \\
CAI-24 + IC-76 & 7.78 & 33 & 6.0 & 33 & 2620 & 73.6 & 2.42 \\
CAI-121 + IC-76 & 9.06 & 35 & 6.2 & 35 & 2942 & 98.6 & 2.64 \\
CAI-127 + IC-76 & 7.84 & 30 & 6.3 & 30 & 2062 & 74.2 & 1.76 \\
KAI-32 + IC-76 & 7.46 & 30 & 5.6 & 30 & 3356 & 103.3 & 2.56 \\
KAI-90 + IC-76 & 7.29 & 27 & 5.6 & 27 & 2053 & 93.3 & 1.73 \\
Consortia + IC-76 & 8.73 & 36 & 6.7 & 36 & 2620 & 106.8 & 2.31 \\
Mean & 7.65 & 30 & 5.7 & 30 & 2546 & 86.1 & 2.22 \\
SE \pm & $0.197 * * *$ & $0.9 * * *$ & $0.22 * * *$ & $1.1 * * *$ & $133.2 * *$ & $1.85 * * *$ & $0.060^{* * *}$ \\
LSD (5 \%) & 0.659 & 3.2 & 0.73 & 3.6 & 445.5 & 6.19 & 0.199 \\
CV \% & 4 & 5 & 5 & 5 & 7 & 3 & 4
\end{tabular}

$S E$ standard error, $L S D$ least significant difference, $C V$ coefficient of variance

** Statistically significant at 0.01

*** Statistically significant at 0.001

Table 4 Effect of IC-76 for their PGP potential in chickpea under on-station field conditions-at 30 days after sowing

\begin{tabular}{llllll}
\hline Treatments & $\begin{array}{l}\text { Plant } \\
\text { height } \\
(\mathrm{cm})\end{array}$ & $\begin{array}{l}\text { Nodule } \\
\text { number } \\
\left(\text { plant }^{-1}\right)\end{array}$ & $\begin{array}{l}\text { Nodule } \\
\text { weight } \\
\left(\mathrm{mg} \mathrm{plant}^{-1}\right)\end{array}$ & $\begin{array}{l}\text { Root } \\
\text { weight } \\
\left(\mathrm{mg} \mathrm{plant}^{-1}\right)\end{array}$ & $\begin{array}{l}\text { Shoot } \\
\text { weight } \\
\left(\mathrm{g} \mathrm{plant}^{-1}\right)\end{array}$ \\
\hline IC-76 & 32 & 52 & 235 & 193 & 2.08 \\
Control & 29 & 49 & 222 & 168 & 1.72 \\
Mean & 31 & 51 & 229 & 181 & 1.90 \\
SE \pm & $0.4^{*}$ & $0.4^{*}$ & $0.8^{* *}$ & $3.8^{*}$ & $0.025^{* *}$ \\
LSD (5 \%) & 2.5 & 2.5 & 5.0 & 23.1 & 0.149 \\
CV \% & 2 & 1 & 1 & 4 & 2
\end{tabular}

$S E$ standard error, $L S D$ least significant difference, $C V$ coefficient of variance

* Statistically significant at 0.05

** Statistically significant at 0.01

inoculated control. However, when IC-76 was combined with individual Streptomyces sp., only available phosphorus was enhanced by all five treatments whereas for total $\mathrm{N}$ and $\%$ organic carbon, only three of the treatments (CAI$24+\mathrm{IC}-76$, CAI-121 + IC-76, and KAI-32 + IC-76) could enhance (Table 3). Though the IC-76 enhanced chickpea plant growth significantly the enhancement was even greater when it was combined with the five Streptomyces sp. Valverde et al. (2006) observed increased chickpea growth performance and seed yield by $52 \%$ when $P$. jessenii PS06 co-inoculated with Mesorhizobium ciceri $\mathrm{C}-2 / 2$ under greenhouse and field conditions. Dey et al. (2004) recorded enhanced yield performance and nodule weight on peanut by a consortium of $P$. fluorescens
Table 5 Effect of IC-76 for their PGP potential in chickpea under on-station field conditions-at harvest

\begin{tabular}{lllllll}
\hline Treatments & $\begin{array}{l}\text { Stover } \\
\text { yield } \\
\left(\mathrm{t} \mathrm{ha}^{-1}\right)\end{array}$ & $\begin{array}{l}\text { Grain } \\
\text { yield } \\
\left(\mathrm{t} \mathrm{ha}^{-1}\right)\end{array}$ & $\begin{array}{l}\text { TDM } \\
\left(\mathrm{t} \mathrm{ha}^{-1}\right)\end{array}$ & $\begin{array}{l}\text { Pod } \\
\text { weight } \\
\left(\mathrm{g} \mathrm{plant}^{-1}\right)\end{array}$ & $\begin{array}{l}\text { Seed } \\
\text { number } \\
\left(\mathrm{plant}^{-1}\right)\end{array}$ & $\begin{array}{l}1000 \\
\text { seed } \\
\text { weight } \\
(\mathrm{g})\end{array}$ \\
\hline IC-76 & 2.43 & 2.01 & 4.44 & 21.92 & 82 & 198 \\
Control & 1.68 & 1.77 & 3.44 & 21.65 & 80 & 197 \\
Mean & 2.05 & 1.89 & 3.94 & 21.78 & 81 & 197 \\
SE \pm & $0.073 *$ & $0.011^{* *}$ & $0.073 * *$ & $0.028^{*}$ & $0.4 *$ & $0.3 *$ \\
LSD (5 \%) & 0.445 & 0.066 & 0.442 & 0.172 & 2.2 & 1.4 \\
CV \% & 6 & 1 & 3 & 1 & 1 & 1
\end{tabular}

$T D M$ total dry matter, $S E$ standard error, $L S D$ least significant difference, $C V$ coefficient of variance

* Statistically significant at 0.05

** Statistically significant at 0.01

strains PGPR1, PGPR2, and PGPR4. Root development of plants plays key role in nutrient management and enhanced plant growth. The five Streptomyces sp. used in this study were also reported earlier to have PGP traits in both sorghum as well as rice (Gopalakrishnan et al. 2013b). Hence, it is concluded that both IC-76 and the five Streptomyces sp. has the potential for PGP in chickpea.

Under on-station field conditions, at 30 days after sowing, IC-76 significantly enhanced plant height (10\%), nodule number $(6 \%)$ and weight $(6 \%)$, root weight $(15 \%)$ and shoot weight $(21 \%)$ while at harvest, stover yield $(45 \%)$, grain yield $(14 \%)$ and total dry matter $(29 \%)$ over the un-inoculated control (Tables 4, 5). The total $\mathrm{N}$, available $\mathrm{P}$, and \% organic carbon were 
Table 6 Effect of IC-76 on soil nutrient properties and biological activities at flowering and harvest stages of chickpea under on-station field conditions

\begin{tabular}{|c|c|c|c|c|c|c|}
\hline \multicolumn{4}{|c|}{ At flowering stage } & \multicolumn{3}{|l|}{ At harvest stage } \\
\hline Treatments & Total N (ppm) & Available P (ppm) & Organic carbon $(\%)$ & Total N (ppm) & Available P (ppm) & Organic carbon $(\%)$ \\
\hline IC-76 & 707 & 9.6 & 0.55 & 759 & 8.0 & 0.58 \\
\hline Control & 675 & 9.2 & 0.54 & 735 & 6.9 & 0.55 \\
\hline Mean & 691 & 9.4 & 0.54 & 747 & 7.4 & 0.57 \\
\hline $\mathrm{SE} \pm$ & $1.4^{*}$ & $0.02 *$ & $0.001 *$ & $1.4^{*}$ & $0.05 *$ & $0.002 *$ \\
\hline $\operatorname{LSD}(5 \%)$ & 25.4 & 0.32 & 0.013 & 25.4 & 0.95 & 0.032 \\
\hline CV \% & 1 & 1 & 1 & 1 & 1 & 1 \\
\hline
\end{tabular}

$S E$ standard error, $L S D$ least significant difference, $C V$ coefficient of variance

* Statistically significant at 0.05

Table 7 Effect of IC-76 on yield performance of chickpea under on-farm field conditions at Mennipadu and Ramapuram villages

\begin{tabular}{|c|c|c|c|c|c|c|c|c|c|c|c|c|}
\hline \multirow[b]{2}{*}{ Farmer } & \multicolumn{2}{|c|}{$\begin{array}{l}\text { Stover }+ \text { pod } \\
\text { yield }\left(t \mathrm{ha}^{-1}\right)\end{array}$} & \multicolumn{2}{|c|}{$\begin{array}{l}\text { Grain yield } \\
\left(\mathrm{t} \mathrm{ha}^{-1}\right)\end{array}$} & \multicolumn{2}{|c|}{$\begin{array}{l}\text { Shoot weight } \\
\left(\text { g plant }^{-1}\right)\end{array}$} & \multicolumn{2}{|c|}{$\begin{array}{l}\text { Pod weight } \\
\left(\text { g plant }^{-1}\right)\end{array}$} & \multicolumn{2}{|c|}{$\begin{array}{l}\text { Number of pods } \\
\left(\text { plant }^{-1}\right)\end{array}$} & \multicolumn{2}{|c|}{$\begin{array}{l}\text { Number of seeds } \\
\left(\text { plant }^{-1}\right)\end{array}$} \\
\hline & Cont. & Inoc. & Cont. & Inoc. & Cont. & Inoc. & Cont. & Inoc. & Cont. & Inoc. & Cont. & Inoc. \\
\hline \multicolumn{13}{|c|}{ Mennipadu } \\
\hline 1 & 2.54 & 3.57 & 1.40 & 2.23 & 2.15 & 3.05 & 6.8 & 11.6 & 27 & 43 & 26 & 44 \\
\hline 2 & 2.84 & 4.05 & 1.92 & 2.13 & 2.19 & 4.18 & 7.0 & 9.5 & 27 & 38 & 27 & 40 \\
\hline 3 & 2.96 & 3.81 & 1.78 & 2.41 & 3.33 & 3.56 & 8.2 & 11.4 & 33 & 40 & 34 & 41 \\
\hline 4 & 3.57 & 4.31 & 1.94 & 2.54 & 3.41 & 3.76 & 9.2 & 9.5 & 35 & 37 & 36 & 37 \\
\hline Mean & 2.98 & 3.93 & 1.76 & 2.33 & 2.77 & 3.64 & 7.8 & 10.5 & 30 & 40 & 31 & 41 \\
\hline $\mathrm{SE} \pm$ & \multicolumn{2}{|c|}{$0.035 * * *$} & \multicolumn{2}{|c|}{$0.035^{* * *}$} & \multicolumn{2}{|c|}{$0.126 * * *$} & \multicolumn{2}{|c|}{$0.10 * * *$} & \multicolumn{2}{|c|}{$0.4 * * *$} & \multicolumn{2}{|l|}{$0.3 * * *$} \\
\hline $\mathrm{CV} \%$ & \multicolumn{2}{|l|}{4} & \multicolumn{2}{|c|}{6} & \multicolumn{2}{|l|}{14} & \multicolumn{2}{|c|}{4} & \multicolumn{2}{|l|}{4} & \multicolumn{2}{|c|}{3} \\
\hline \multicolumn{13}{|c|}{ Ramapuram } \\
\hline 1 & 4.70 & 6.03 & 2.86 & 3.25 & 8.30 & 8.68 & 17.6 & 21.2 & 50 & 60 & 51 & 60 \\
\hline 2 & 4.98 & 6.62 & 3.03 & 3.96 & 4.29 & 4.80 & 16.5 & 18.9 & 48 & 57 & 47 & 56 \\
\hline 3 & 5.11 & 6.62 & 3.27 & 3.74 & 5.03 & 5.30 & 19.9 & 20.2 & 54 & 56 & 55 & 57 \\
\hline 4 & 5.50 & 6.37 & 2.65 & 3.48 & 6.38 & 7.06 & 13.1 & 19.6 & 38 & 47 & 39 & 54 \\
\hline Mean & 5.07 & 6.41 & 2.95 & 3.61 & 6.00 & 6.46 & 16.8 & 19.9 & 48 & 55 & 48 & 57 \\
\hline $\mathrm{SE} \pm$ & \multicolumn{2}{|c|}{$0.047 * * *$} & \multicolumn{2}{|c|}{$0.036^{* * *}$} & \multicolumn{2}{|c|}{$0.031 * * *$} & \multicolumn{2}{|c|}{$0.36 * * *$} & \multicolumn{2}{|c|}{$0.6^{* * *}$} & \multicolumn{2}{|c|}{$0.5 * * *$} \\
\hline $\mathrm{CV} \%$ & \multicolumn{2}{|c|}{2} & \multicolumn{2}{|c|}{4} & \multicolumn{2}{|c|}{2} & \multicolumn{2}{|c|}{7} & \multicolumn{2}{|l|}{4} & \multicolumn{2}{|c|}{3} \\
\hline
\end{tabular}

Cont. control, Inoc. inoculated with IC 76 strain, $S E$ standard error, $C V$ coefficient of variance

*** Statistically significant at 0.001

significantly higher in the top $15 \mathrm{~cm}$ of rhizosphere soils of IC-76 treated plants by 5,4 , and $2 \%$, respectively, at flowering stage and by 3,16 , and $6 \%$, respectively, at harvesting stage over the un-inoculated control (Table 6). Under on-farm field conditions, at Mennipadu and Ramapuram villages, IC-76 significantly enhanced stover yield (up to 43 and $33 \%$, respectively), grain yield (up to 59 and $31 \%$, respectively), shoot weight (up to 91 and $12 \%$, respectively), pod weight plant ${ }^{-1}$ (up to 71 and $50 \%$, respectively), pod numbers plant ${ }^{-1}$ (up to 59 and $24 \%$, respectively), and seed number plant ${ }^{-1}$ (up to 69 and $39 \%$, respectively) over un-inoculated control in all the four farmer's fields (Table 7).
In the present investigation, under on-station chickpea field conditions, IC-76 significantly enhanced plant height, nodule number and weight, root and shoot weight, stover yield (45\%), grain yield (14\%), and total dry matter $(29 \%)$ over the un-inoculated control (Table 5). Similar results were found when IC-76 was evaluated on chickpea at on-farm conditions at Mennipadu and Ramapuram villages of Andhra Pradesh, India where stover yield (up to 43 and $33 \%$, respectively) and grain yield (up to 59 and $31 \%$, respectively) were enhanced over the un-inoculated control (Table 7). The mechanism by which the IC-76 enhanced the PGP on chickpea could be their PGP traits including IAA and siderophore production (direct 


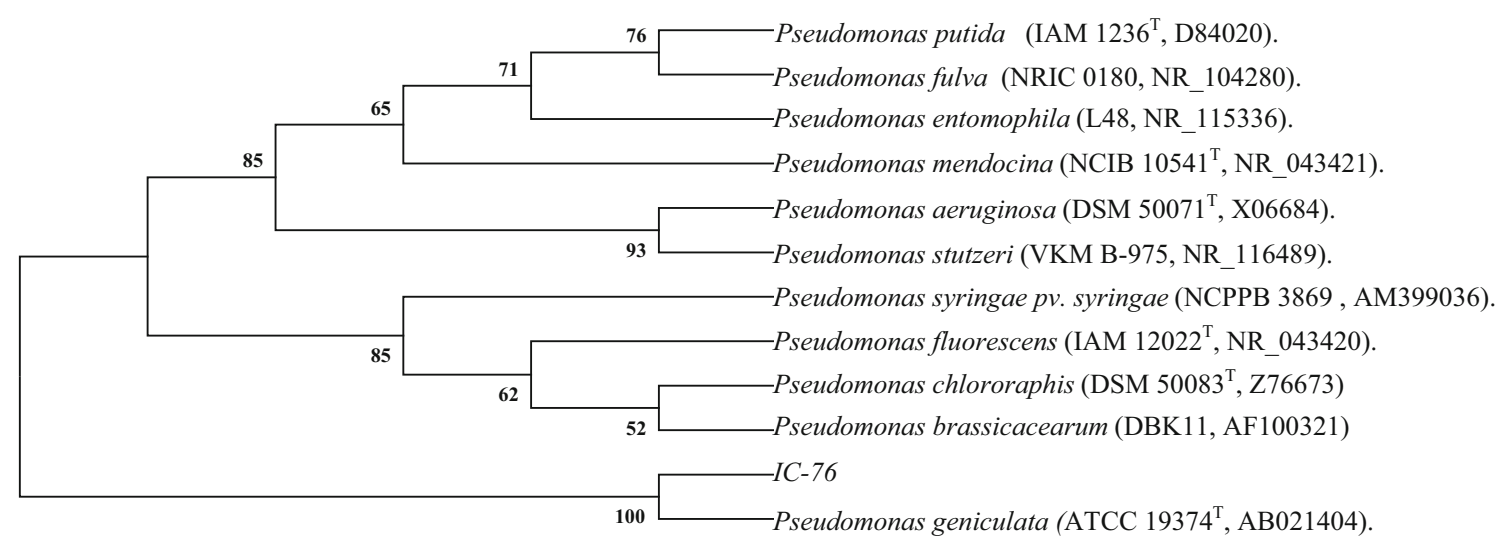

Fig. 1 Phylogenetic relationship between IC-76 and representative species based on full length 16S rDNA sequences constructed using the neighbor-joining method

simulation of PGP) and $\mathrm{HCN}$, cellulase, protease, and $\beta$-1,3-glucanase (indirect stimulation of PGP; Table 1). The effect of bacteria on PGP including root development has been widely reported (Birkhofer et al. 2008; El-Tarabily 2008; Uphoff et al. 2009; Gopalakrishnan et al. 2012a, 2013a, 2014). In the present investigation, although, chickpea roots were not inspected for colonization, the repeated data on root morphology (including root weight, length, and volume) and soil chemical activities (including $\%$ organic carbon, total $\mathrm{N}$, and available $\mathrm{P}$ ) in greenhouse and on-station field conditions strongly suggest that the IC76 had multiplied and colonized the roots of chickpea plants. Mercado-Blanco and Bakker (2007) reported series of research work on $P$. fluorescens WCS365 ability to colonize plant roots. Therefore, it can be concluded that the IC-76 was able to survive in the chickpea rhizosphere, colonize on the chickpea roots, and promote PGP and enhance soil health.

To identify the IC-76, its 16S rDNA was sequenced and analyzed. A neighbor-joining dendrogram was generated using the sequence from IC-76 (857 bp) and representative sequences from the databases. Phylogenetic analysis of $16 \mathrm{~S}$ rDNA sequence of IC-76 showed maximum sequence similarity (100\%) with Pseudomonas geniculata (Fig. 1). When the nucleotide sequences were submitted, GenBank assigned NCBI accession number KM 581022 for IC-76. Several species of Pseudomonas such as $P$. aeruginosa (Ganesan 2008), P. fluorescens (Shaharoona et al. 2006), $P$. putida (Tripathi et al. 2005), P. jessenii (Rajkumar and Freitas 2008), and P. chlororaphis (Liu et al. 2007) also have been documented for one or multiple PGP traits. Enhanced plant growth performance and soil nutrient parameters has been observed in pot studies on various Pseudomonas sp., as individual culture on (i) mung bean by Pseudomonas sp. (Gupta et al. 2002), P. putida KNP9 (Tripathi et al. 2005); (ii) soybean by P. fluorescens (Gupta et al. 2005) and (iii) black gram by $P$. aeruginosa (Ganesan
2008). Mesorhizobium sp. and Bacillus sp. and even Pseudomonas sp. have been demonstrated for their PGP in chickpea under greenhouse conditions (Parmer and Dadarwal 1999; Tank and Saraf 2009; Ahemad and Khan 2010; Wani and Khan 2010), however, as of the author's knowledge; there are no reports of $P$. geniculata demonstrated for PGP potentials in chickpea or any other crop under field conditions. Hence, this is the first report acknowledging PGP potential of $P$. geniculata under laboratory, green house, on-station and on-farm field conditions on chickpea. The PGP traits of the P. geniculata IC-76 and its effect on chickpea plant growth and yield suggest that this strain has a potential of being developed as bio-inoculant and hence is more likely to be a promising strain for application in agriculture under semi-arid conditions.

Acknowledgments This work has been undertaken as part of the CGIAR Research Program on Grain Legumes. We also thank all the staff of the biocontrol unit of ICRISAT including M/s PVS Prasad, P Manohar, B Nagappa, D Barath, A Jabbar, and S Rohini for their significant inputs in the laboratory and field studies.

Conflict of interest All the authors declare that they have no financial/commercial conflicts of interest.

Open Access This article is distributed under the terms of the Creative Commons Attribution License which permits any use, distribution, and reproduction in any medium, provided the original author(s) and the source are credited.

\section{References}

Ahemad M, Khan MS (2010) Improvement in the growth and symbiotic attributes of fungicide-stressed chickpea plants following plant growth-promoting fungicide-tolerant Mesorhizobium inoculation. Afr J Basic Appl Sci 2:111-116

Ahemad M, Kibret M (2014) Mechanisms and applications of plant growth promoting rhizobacteria: current perspective. J King Saud University 26:1-20 
Alschul SF, Gish W, Miller W, Myers EW, Lipman DJ (1990) Basic local alignment search tool. J Mol Biol 215:403-410

Basak BB, Biswas DR (2009) Influence of potassium solubilizing microorganisms (Bacillus mucilaginosus) and waste mica on potassium uptake dynamics by sudan grass (Sorghum vulgare Pers.) grown under two Alfisols. Plant Soil 317:235-255

Bazzicalupo M, Fani R (1995) The use of RAPD for generating specific DNA probes for microorganisms. In: Clap JP (ed) Methods in molecular biology, species diagnostic protocols: PCR and other nucleic acid methods. Humana Press Inc, Totowa, pp 112-124

Bhattacharya A, Chandra S, Barik S (2009) Lipase and protease producing microbes from the environment of sugar beet field. Ind J Agric Bio chem 22:26-30

Birkhofer K, Bezemer TM, Bloem J, Bonokowski M, Chritensen S, Dubois D, Ekelund F, Fliessbach A, Gunst L, Hedlund K, Mader P, Mikola J, Robin C, Setala H, Tatin-Froux F, Van der Putten W, Scheu S (2008) Long-term organic farming fosters below and above ground biota; implications for soil quality, biological control and productivity. Soil Biol Bio chem 40:2297-2308

Cheng Z, Park E, Glick BR (2007) 1-Aminocyclopropane-1carboxylate deaminase from Pseudomonas putida UW4 facilitates the growth of canola in the presence of salt. Can $\mathbf{J}$ Microbiol 53:912-918

Dey R, Pal KK, Bhatt DM, Chauhan SM (2004) Growth promotion and yield enhancement of peanut (Arachishypogaea L.) by application of plant growth-promoting rhizobacteria. Microbiol Res 159:371-394

El-Tarabily KA (2008) Promotion of tomato (Lycopersiconesculentum Mill.) plant growth by rhizosphere competent 1 -aminocyclopropane-1-carboxylic acid deaminase-producing Streptomycete actinomycetes. Plant Soil 308:161-174

Figueiredo MVB, Martinez CR, Burity HA, Chanway CP (2008) Plant growth-promoting rhizobacteria for improving nodulation and nitrogen fixation in the common bean (Phaseolus vulgaris L.). World J Microbiol Biotechnol 24:1187-1193

Ganesan V (2008) Rhizoremediation of cadmium soil using a cadmium-resistant plant growth-promoting rhizopseudomonad. Curr Microbiol 56:403-407

Glick BR (1995) Enhancement of plant growth by free-living bacteria. Can J Microbiol 41:109-117

Gopalakrishnan S, Humayun P, Kiran BK, Kannan IGK, Vidya MS, Deepthi K, Rupela O (2011a) Evaluation of bacteria isolated from rice rhizosphere for biological control of sorghum caused by Macrophomina phaseolina. World J Microbiol Biotechnol 27:1313-1321

Gopalakrishnan S, Kiran BK, Humayun P, Vidya MS, Deepthi K, Rupela O (2011b) Biocontrol of charcoal-rot of sorghum by actinomycetes isolated from herbal vermi-compost. Afr J Biotechnol 10:18142-18152

Gopalakrishnan S, Pande S, Sharma M, Humayun P, Kiran BK, Sandeep D, Vidya MS, Deepthi K, Rupela O (2011c) Evaluation of actinomycete isolates obtained from herbal vermi-compost for biological control of Fusarium wilt of chickpea. Crop Protect 30:1070-1078

Gopalakrishnan S, Humayun P, Vadlamudi S, Vijayabharathi R, Bhimineni RK, Rupela O (2012a) Plant growth-promoting traits of Streptomyces with biocontrol potential isolated from herbal vermicompost. Biocontrol Sci Technol 22:1199-1210

Gopalakrishnan S, Upadhyaya HD, Vadlamudi S, Humayun P, Vidya MS, Alekhya G, Singh A, Vijayabharathi R, Bhimineni RK, Seema M, Rathore A, Rupela O (2012b) Plant growth-promoting traits of biocontrol potential bacteria isolated from rice rhizosphere. SpringerPlus 1:1-7

Gopalakrishnan S, Vadlamudi S, Apparla S, Bandikinda P, Vijayabharathi R, Bhimineni R, Rupela O (2013a) Evaluation of
Streptomyces sp. for their plant growth-promotion traits in rice. Can J Microbiol 59:534-539

Gopalakrishnan S, Srinivas V, Vidya MS, Rathore A (2013b) Plant growth-promoting activities of Streptomyces sp. in sorghum and rice. SpringerPlus 2(1):574

Gopalakrishnan S, Vadlamudi S, Bandikinda P, Satya A, Vijayabharathi R, Rupela O, Kudapa H, Katta K, Varshney RV (2014) Evaluation of Streptomyces strains isolated from herbal vermicompost for their plant growth-promotion traits in rice. Microbial Res 169:40-48

Gupta A, Meyer JM, Goel R (2002) Development of heavy metal resistant mutants of phosphate solubilizing Pseudomonas sp. NBRI4014 and their characterization. Curr Microbiol 45:323-332

Gupta A, Rai V, Bagdwal N, Goel R (2005) In situ characterization of mercury resistant growth promoting fluorescent pseudomonads. Microbiol Res 160:385-388

Haas D, Keel C, Laville J, Maurhofer M, Oberhansli T, Schnider U, Voisard C, Wuthrich B, Defago G (1991) Secondary metabolites of Pseudomonas fluorescens strain CHAO involved in the suppression of root diseases. In: Hennecke H, Verma DPS (eds) Advances in molecular genetics of plant-microbe interactions, vol 11. Kluwer Academic Publishers, Dordrecht, pp 450-456

Hao D, Gao P, Liu P, Zhao J, Wang Y, Yang W, Lu Y, Shi T, Zhang $X$ (2011) AC3-33, a novel secretory protein, inhibits Elk1 transcriptional activity via ERK pathway. Mol Biol Rep 38:1375-1382

Hendricks CW, Doyle JD, Hugley B (1995) A new solid medium for enumerating cellulose-utilizing bacteria in soil. Appl Environ Microbiol 61:2016-2019

Hirano S, Nagao N (1988) An improved method for the preparation of colloidal chitin by using methanesulfonic acid. Agric Biol Chem 52:2111-2112

Indiragandhi P, Anandham R, Madhaiyan M, Sa TM (2008) Characterization of plant growth-promoting traits of bacteria isolated from larval guts of diamondback moth Plutellaxylostella (Lepidoptera; Plutellidae). Curr Microbiol 56:327-333

Joshi FR, Kholiya SP, Archana G, Desai AJ (2008) Siderophore cross-utilization amongst nodules isolates of the cowpea miscellany group and its effect on plant growth in the presence of antagonistic organisms. Microbial Res 163:564-570

Kumar H, Dubey RC, Maheshwari DK (2011) Effect of plant growthpromoting rhizobia on seed germination, growth promotion and suppression of Fusarium wilt of fenugreek (Trigonellafoenumgraecum L.). Crop Protect 30:1396-1403

Lima LHC, Marco JL, Felix JR (1998) Enzimas hidroliticasenvolvidas no controle biologico por miciparasitisma. In: Melo IS, Azevedo JL, (eds) Controle biologico. 11 Jaguraiuna: EMBRAPA-Meio Ambiente, 263-304

Liu H, He Y, Jiang H, Peng H, Huang X, Zhang X, Thomashow LS, $\mathrm{Xu} \mathrm{Y}$ (2007) Characterization of a phenazine producing strain Pseudomonas chlororaphis GP72 with broad spectrum antifungal activity from green pepper rhizosphere. Curr Microbiol 54:302-306

Lorck H (1948) Production of hydrocyanic acid by bacteria. Physiol Planta 1:142-146

Mercado-Blanco J, Bakker PAHM (2007) Interactions between plants and beneficial Pseudomonas spp.: exploiting bacterial traits for crop protection. Antonie Van Leeuwenhoek 92:367-389

Minorsky PV (2008) On the inside. Plant Physiol 146:323-324

Nassar AH, El-Tarabily KA, Sivasithamparam K (2003) Growth promotion of bean (Phaseolus vulgaris L.) by a polyamine producing isolate of Streptomyces griseoluteus. Plant Growth Reg 40:97-106

Nelson DW, Sommers LE (1982) Total organic carbon and organic matter. In: Page AL, Miller RH, Keeney DR (eds) Methods of 
soil analysis; Part 3, Chemical and microbiological properties. Madison, SSSA, pp 539-579

Novozamsky I, Houba VJG, Van ECKR, vanVark W (1983) A novel digestion technique for multiple element analysis. Commun Soil Sci Plant Anal 14:239-249

Olsen SR, Sommers LE (1982) Phosphorus. In: Page AL (ed) Methods of soil analysis, Agronomy No. 9, Part 2, 'chemical and microbial properties', 2nd edn. Madison, USA Am Soc Agron, pp 403-430

Pandey P, Maheshwari DK (2007) Two-species microbial consortium for growth promotion of Cajanascajan. Curr Sci 92:1137-1142

Pandey P, Kang SC, Maheswari DK (2005) Isolation of endophytic plant growth-promoting Burkholderia spp. MSSP from root nodules of Mimosa pudica. Curr Sci 89:177-180

Panhwar QA, Othman R, Rahman ZA, Meon S, Ismail MR (2012) Isolation and characterization of phosphate-solubilizing bacteria from aerobic rice. Afr J Biotechnol 11:2711-2727

Parmer N, Dadarwal KR (1999) Stimulation of nitrogen fixation and induction of flavonoid like compounds by rhizobacteria. J Appl Microbiol 86:36-44

Patten C, Glick BR (1996) Bacterial biosyntehsis of indole-3-acetic acid. Can J Microbiol 42:207-220

Patten C, Glick CR (2002) Role of Pseudomonasputida indole acetic acid in development of host plant root system. Appl Environ Microbiol 68:3795-3801

Pikovskaya RI (1948) Mobilization of phosphorus in soil connection with the vital activity of some microbial species. Microbiologia 17:362-370

Rajkumar M, Freitas H (2008) Effects of inoculation of plant growthpromoting bacteria on Ni uptake by Indian mustard. Bioresour Technol 99:3491-3498

Rajkumar M, Ae N, Prasad MNV, Freitas H (2010) Potential of siderophore-producing bacteria for improving heavy metal phytoextraction. Trends Biotechnol 28:142-149

Riggs PJ, Chelius MK, Iniguez AL, Kaeppler SM, Triplett EW (2001) Enhanced maize productivity by inoculation with diazotrophic bacteria. Aust J Plant Physiol 28:829-836

Sadeghi A, Karimi E, Dahazi PA, Javid MG, Dalvand Y, Askari H (2012) Plant growth-promoting activity of an auxin and siderophore producing isolate of Streptomyces under saline soil condition. World J Microbiol Biotechnol 28:1503-1509

Saitou N, Nei M (1987) The neighbor-joining method: a new method for reconstructing phylogenetic trees. Mol Biol Evol 4:406-425

Schwyn B, Neilands JB (1987) Universal chemical assay for the detection and determination of siderophores. Anal Biochem $160: 47-56$
Shaharoona B, Arshad M, Zahir ZA (2006) Effect of plant growthpromoting rhizobacteria containing ACC-deaminase on maize (Zea mays L.) growth under axenic conditions and on nodulation in mung bean. Lett Appl Microbiol 42:155-159

Singh PP, Shin YC, Park CS, Chung YR (1999) Biological control of Fusarium wilt of cucumber by chitinolyticbacteria. Phytopathology 89:92-99

Soares RA, Roesch LPW, Zanatta G, Camargo FAD, Passaglia LMP (2006) Occurrence and distribution of nitrogen fixing bacterial community associated with oat (Avena sativa) assessed by molecular and microbiological techniques. Appl Soil Ecol 33:221-234

Tamura K, Dudley J, Nei M, Kumar S (2007) MEGA4: molecular evolutionary genetics analysis (MEGA) software version 4.0. Mol Biol Evol 24:1596-1599

Tank N, Saraf M (2009) Enhancement of plant growth and decontamination of nickel-spiked soil using PGPR. J Basic Microbiol 49:195-204

Thompson JD, Gibsom TJ, Plewniak F, Jeanmougin F, Higgins DG (1997) TheclustalX windows interface: flexible strategies for multiple sequence alignment aided by quality analysis tools. Nucleic Acids Res 24:4876-4882

Tokala RK, Strap JL, Jung CM, Crawford DL, Salove MH, Deobald LA, Bailey JF, Morra MJ (2002) Novel plant-microbe rhizosphere interaction involving Streptomyceslydicus WYEC108 and the pea plant (Pisumsativum). Appl Environ Microbiol 68:21612171

Tripathi M, Munot HP, Shouch Y, Meyer JM, Goel R (2005) Isolation and functional characterization of siderophore-producing leadand cadmium-resistant Pseudomonas putida KNP9. Curr Microbiol 5:233-237

Uphoff N, Anas I, Rupela OP, Thakur AK, Thyagarajan TM (2009) Learning about positive plant-microbial interactions from the system of rice intensification (SRI). Aspect Appl Biol 98:29-54

Valverde A, Burgos A, Fiscella T, Rivas R, Velazquez E, RodriguezBarrueco C, Cervantes E, Chamber M, Igual JM (2006) Differential effects of co-inoculations with Pseudomonasjessenii PS06 (a phosphate-solubilizing bacterium) and Mesorhizobiumciceri C-2/2 strains on the growth and seed yield of chickpea under greenhouse and field conditions. Plant Soil 287:43-50

Vessey KJ (2003) Plant growth promoting rhizobacteria as biofertilizers. Plant Soil 255:571-586

Wani PA, Khan MS (2010) Bacillus species enhance plant growth parameters of chickpea (Cicer arietinum L.) in chromium stressed soils. Food Chem Toxicol 48:3262-3267 